\title{
King Zog's Foreign Policy with Neighboring Countries
}

\author{
Emirjola Yzeiraj \\ Lecturer and PhD Candidate, \\ University of Tirana
}

DOI: https://doi.org/10.36941/mjss-2021-0049

\begin{abstract}
Zogu has resolutely defended the freedom and independence of his country. Zogu consolidated diplomatic relations with neighboring countries and the political strategy followed by him brought not only economic stability, but also protection of the territory. Seen from that prespective, the purpose of this paper is to show that the policy pursued by King Zog, influenced the establishment of peace in the country and protected the entire Balkans by not further complicating the situation and neutralizing the greedy interests and intentions of Yugoslavia for the territory of Albania, especially St. Naum. In 1924 King Zog had also a possed Yugoslavia's intervention and intrigues. Throughout his policy, he aimed to achieve Balkan's peace, because Zogu understanding very well that this would bring peace to Albania as well. The foreign policy led by Zog, deprived neighboring countries of any wishing conflicts. Thus the peace in Europe would have been in jeopardy as a result of threatening Balkans's peace.
\end{abstract}

Keywords: Ahmet Zogu, foreign policy, neighboring countries, stabilit

\section{Introduction}

\subsection{Diplomatic Relation with neighboring countries}

The political situation created in Albania, in 1925 brought change in the form of government, from the Republic to the Monarchy, from under the support of Mussolini, Ahmet Zogu was proclaimed King. The conditions in which Zogu came to power were crucial to the diplomatic relations between Albania and neighboring countries. The two neighboring countries with which King Zog consolidated diplomatic relations as well as internal political stability were Italy and Yugoslavia.

Zog's return to power provoked mixed reactions from Yugoslavia and Italy. Italy was really pleased and convinced that it had achieved a difficult but important undertaking to protect its interests in Albania. Unlike the Serbs, public opinion and the Italian government found it strange how things came to be. The events within Albania took a bad turn, which led to a feeling of regret. What happened reminded them of the "distant departure of the Italians from Vlora" and even worse "the same people of that time had come to power". Mussolini usually mentioned the Italian withdrawal from Albania in 1920 as one of the humiliations that would be hidden from fascism: 'When I heard about the evacuation of Vlora, I cried'. And this is not just a rhetorical phrase. "What the impression expressed was that with the return of Zogu, Yugoslavia had gained what it had 
previously lost to Fiume, returning in 1923 Eyres would have rejected such a belief. In a secret letter from Foreign Secretary George Nathaniel Curzon ${ }^{2}$ on June 6, 1923, he stated: "... I dare say that it is not correct to speak of serious tendencies of the albanian government. More than once I have opposed their intention to get support from one of the neighboring countries; "Moreover, their policy has been to develop friendly relations with Greece, Yugoslavia or even Italy, yet their methods may once have been very poor."3

The Serbo-Croatian-Slovenian government, unable to financially support a weak Albania, believed that by helping Zogu return to power, he would make more political concessions to the Yugoslavs, thus avoiding a future Italian influence, which sooner or later would bring Italian Troops to Albania, who they were afraid of. On the other hand, Mussolini was convinced that the precondition for Italian expansion into north-eastern Africa and the Middle East was the informal domination of the Balkans and the Eastern Mediterranean, thus balancing French supremacy in the western Mediterranean. The first obstacle to this strategy was Yugoslavia, a fiery new creation with the courage to act as a regional power. Mussolini decided to cut the Serbs to size and Albania could still be the means to do so. By now, no opportunity should be lacking to boost Italian influence in Tirana.

Belgrade knew the Italian intentions, yet the Yugoslav ruling circles were aware of their powerlessness to drive Italy away from Albania. That is why they initiated the idea of dividing it between the two countries. When King Alexander went to Paris in January 1925, he met with the Italian ambassador there and suggested a possible division of their spheres of interest in Albania. ${ }^{4}$ The Italian government rejected such a proposal in light of the guarantees offered by Zogu and furthermore, because it was necessary to bring the whole of Albania under close control to carry out its projects in the Balkans. The idea of partition was also rejected by the UK, following in the footsteps of its policy in the region. Instead, His Majesty's government tried to control this rivalry between the two and maintain peace in the Balkans. However, everything depended on Zog's perspective and his approach. The relationship remained turbulent and neighboring countries wanted to take advantage of Albania one as a strategic point, the other as a territory occupier. In December 1925, Eyres reported to the Foreign Office as follows: "I do not know what will happen to this country, but it is my conviction that Serbs or Italians want an unstable Albania and will "devote all their efforts to this end ... Anyway, I will do everything to show Zogu the right direction. However, there is little hope, but I have to try it."5 The great powers, seeing the miserable situation of Albania, especially from the economic point of view, decided to make a withdrawal to further exercise control over the government and over Albania, from where this would come as a result of giving power to the government of Ahmet Zogu and intervene in full control of the country. This brought relief to neighboring countries as Albania was a geographically favored country.

Due to Albania's delicate position between two almost powerful neighbors, which could easily provoke a conflict, Eyres suggested neutralizing Albania: the country's integrity must be guaranteed jointly or individually by Italy, the Serbo-Croatian-Slovenian Kingdom and Greece. , as countries mainly and directly interested in Albania and from Great Britain and France, as the only Great Powers that are in Europe. ${ }^{6}$ But Albania was too weak to defend its neutrality against any possible violations. Moreover, state borders had been established, they had never been satisfactory to Albanians and thus could be subject to looting and clashes between Albanians and Serbs at any time. In such circumstances, the Foreign Office concluded that Albania's neutrality could cause war rather than peace. Consequently, the UK suggested that it was advisable to try and hold the hands of all

21st Marquess Curzon of Kedleston FO 371/8535, Dibra op. cit. p. 226

31st Marquess Curzon of Kedleston FO 371/8535, Dibra op. cit. p. 226

4Milo,Paskal, Politika e Jashtme e Shqipërisë, Botimet Toena, fq. 334-335,

5DBFP; vol. XXVI, doc. 312, n.5, 25 December 1925 : (Foreign Policy Documents, Archival Reference) 
neighbors outside Albania and refer to the most important issues in the League of Nations before a state was engaged in that country.

Seeing the situation in which the country was, by no means Ahmet Zogu with his political cunning could allow a decline and a failure of the country. Therefore, King Zog, in addition to reorganizing state power, sought to define the main lines of his foreign policy. In the normal course of events he should have been biased towards Yugoslavia because of his contribution to the counterrevolution and above all for the sake of his agreement with Pašić. However, Rome or Belgrade were skeptical of his stance after coming to power. Despite his absolute and formal assurances to the Italian Minister Marquis Durazzo and Eyres, in January 1925, no conditions had been set for him and moreover, there was no compromise of any kind with Pasic, Rome had gathered sufficient Information. to raise suspicions of a secret agreement signed between Zogu and Pašic, which allowed Yugoslavia to continue knocking at Albania's door. ${ }^{7}$ Mussolini could not cope with such a situation that could hinder the achievement of his goals in the Balkans. From the beginning of January he had made it clear that the Italian government was determined to do everything to guarantee what had already been set out in international acts concerning Albania, e.g. the privileged position of Italy. He informed the Italian envoy in Durrës that he would refuse to recognize Zog's government unless he proved that he was independent and guaranteed Italy the position he expected. ${ }^{8}$

In a telegram to Durrës on January 7,1925 , Mussolini seemed particularly concerned when he stated that: "The special circumstances in which Ahmet Zogu's return to Albania and to power took place, as Your Excellency emphasized, have convinced our public opinion that official Serbian or Yugoslav cross-border circles most likely sheltered him .... He may have been bound by promises which could limit his independence against Belgrade and thus were forced by Serbia to establish its dominant position in Albania ".9

Despite the situation created between the two countries, the stability and regulation of relations was important because it brought economic benefits between the countries, but it also brought ease to the relations with other neighboring countries. In these important moments for the government of Ahmet Zogu was the maintenance of diplomatic relations with all countries for a political stability.

\section{Albania-Yugoslavia relations and discussions on territories}

Problems arose precisely with the Yugoslav government from where, it was a territorial problem that led to conflict and breakdown of relations between the two countries. What was intended by Ahmet Zogu was precisely to find a problem to enable stability and to bring a development and ensure the continuation of diplomatic relations with neighboring countries. Because this helped Albania a lot in terms of economical development.

A move took place not directly, but became the basis of a secret agreement. What was in fact the truth of the secret pact between Zog and Pašic in August 1924? While in Belgrade, Zog managed to persuade Serbs to help overthrow the democratic government, for his decision to stay in Yugoslavia and seek Belgrade's support came as a result of his old relations with Yugoslav political circles since the First World War and after. These relations were never severed even when he was in power. Belgrade was interested in creating a pro-Yugoslav regime in Albania, and Zogu, despite his cunning waysand lack of loyalty, was at the right time to do so. For his part, Zogu had realized that Belgrade would, only in those circumstances, support him by all means to return to power. ${ }^{10}$ He was also convinced that the only way back was military intervention, which could simply start from Yugoslav territory.

The realization of a secret agreement without having anything factual would bring successive changes in the continuation of the political organization and would also decide the fate between the

7Milo, Paskal, Politika e Jashtme e Shqipërisë, Botimet Toena. 333

8 Ushtelenca I., Diplomacia ..., p. 62

9Cici A., Marrëdhëniet ...., p. 62, op. cit. IDD, vol. III, n. 66o, pp. 404-405

10 Milo, Paskal, Politika e Jashtme e Shqipërisë, Botimet Toena. 298 
progress of the friendly relations between the two countries.

The attempt to meet the immediate need for financial means and armaments for his troops led him to the finalization of a secret pact with Yugoslavia that would be Primer Pašić. Pašić was in opposition at the time, but with a good chance of coming to power soon. The truth is that there is no written document that would prove the existence of such an agreement. However, the opposite should be ruled out, as it was signed by two men who were neither in power nor omnipotent (Zogu was an emigrated prime minister while Pašic, was in opposition). Everything was based on the act they did together not by the strength they had nor by the position they held, but accomplished it individually. As researcher Zivko Avramovsky put it, it was a "gentlemen's deal."11

This opinion stands stronger given the other similar agreements previously concluded by Zogu. In 1922, Zogu had made a verbal agreement with Yugoslavia's Foreign Minister, the articles of which Nincic had written in a document preserved to this day in the Yugoslavic archives. Also, in August 1924, Zog had not agreed to write a secret letter to Mussolini at the latter's request seeking financial support. Therefore, this reveals that often and willingly Zogu preferred not to sign a written agreement, but to remain discreet, because his policy was also to achieve personal goals in addition to achieving the welfare and development of the country. ${ }^{12}$

Because everything would change if such an agreement really existed on paper, Belgrade would not continue to keep it a secret in 1926-1927, when its relations with the President of the Republic of Albania were seriously aggravated and a such a document would compromise him before his people and the Great Powers.

The documents stored in the state archive also gave an explanation of the political organization that Ahmet Zogu was part of, in order to make it more realistic.

A document similar to the Zogu-Pašić agreement is stored in the Albanian State Archive. ${ }^{13}$ Another similar document with sixteen points had been presented to and seen by Mussolini. ${ }^{14}$ The latter had come at the same time from two sources. In the second half of November 1925, General Bodrero had sent a telegram transmitting from the Italian defense attaché, Viscont Praska of Belgrade, the text of a secret agreement made between Zog and Pašic in August 1924 $4^{15}$. About two months later, on January 9, 1926, the Italian Chargé d'Affaires in Albania, Assereto, sent to the Italian Ministry of Foreign Affairs the same document reporting that "a person with authority who might have been very well informed"16 had given him, strictly in confidence, a copy of the Agreement, between Zog and Pašić.

This document exactly, brought discussions and had stirred up a lot of controversy, because it shows that the Albanian territory was already divided and the territories were not owned by Albania, but by Yugoslavia.

One of the main points of the agreement stipulates that "the Albanian government will declare before the Conference of Ambassadors in Paris that it rejects any claim of sovereignty over the Monastery of St. Naum and the location of Vermosh and Kelmendi, which will remain in the possession of Yugoslavia." ${ }^{17}$

The content of the Zogu-Pašić Agreement found in the Central Archive of the Albanian State ${ }^{18}$ is identical to the one, mentioned by Pastorelli:

1. Albania will join Yugoslavia in a personal union.

2. At the Head of the Albanian State will be Ahmet Zog, who will later recognize the Karadgeorgevic dynasty.

11Milo,Paskal, Politika e Jashtme e Shqipërisë , Botimet Toena. 298

12 MEPJ, Arkivi historic 1928-1932.

13ASCA, Fund 251, File 105, pp. 4-5, 1925

14Pastorelli P., "Italia e Albania 1924-1927", pp. 221-222

15Ibid., p. 220

16 Ibid., p. 220

17ASCA, Fund 251, File 105, p. 3

18 MEPJ, Arkivi historik 1928-1932. 
3. The Government of Belgrade guarantees the support, with all its diplomatic and military means, of Ahmet Zogu as the head of the Albanian state, now sharing the annual income.

4. The Albanian Ministry of War is abolished and Albania will never have the right to have a national army.

5. Albania will maintain, but a strong gendarmerie, with the sole task of maintaining internal order and suppressing any hostile move against Ahmet Zogu and the regime established by him.

6. This gendarmerie will also recruit the Russian army of General Wrangler's former army that is now in Yugoslavia. The Belgrade government is committed to supporting the gendarmerie with financial means and weapons.

7. Among the officers of this gendarmerie will be the Yugoslavs and others who are considered personal grata by the Serbian, Croatian and Slovenian governments.

8. Albania and Yugoslavia will establish a custom union on the basis of which imports and exports of goods between the two countries will be free. Also, the movement of citizens between the two countries will be free and without passports.

Exactly these points brought controversy of the changes that would take place, because there was a time when the borders of Albania were discussed.

The issue of the Albanian border in St. Naum had been discussed for a long time. In June 1924, the Conference of Ambassadors had decided to present it to the Council of the League of Nations. Such a decision was taken at the suggestion of the British government, which held that the border had already been fixed by the Decision of 6 December 1922. The League Council considered it and concluded that the matter had become a purely legal question, namely whether the decision of the Conference of Ambassadors, which appointed the Monastery in Albania, ended. Thus, the Council voted to refer the matter to the Permanent Court of International Justice in The Hague, almost in the same manner as presented by the Conference of Ambassadors, and both parties to the dispute accepted the Council's recommendations for opinions. ${ }^{19}$ The court was provided with all relevant documents and heard oral statements from representatives of the Yugoslav and Albanian governments, as well as the Greek government. The suggestive opinion, which was unanimous, stated that the legal basis of the decision of November 9, 1921 was found In the fact that the Principal Powers of the Allied Powers, acting through the Conference of Ambassadors, were authorized to take a decision as recognized by the League and the States. Also, the decision of 6 December 1922 was based on the same powers as that of 9 November 1921 and had the same definite character and the same legal effect. The court then discussed the Yugoslav government's claim that it had the right granted by the decision of 9 November 1921, due to confirmation by the 1913 border decision, and concluded that the 1913 London Protocol could not be considered that the monastery of St. Naum was attributed to Serbia. This brought about the change and the claim of the property right by the Albanian government. ${ }^{20}$

It ensured that the region "as far as the Monastery of St. Naum" was to be attributed to Albania, and the Court found it impossible to say which of the two equally possible interpretations of the expression "jusquAu "- inclusive or exclusive, with regard to the new facts which Yugoslavia claims ton exist, the Court found that they consisted merely of documents to which the members of the Conference had access and which, moreover, did not prove that the Monastery of St. Naum was attributed to Serbia in $1913 .{ }^{21}$

The advisory opinion was carried out with such authority that even the Yugoslav delegate to the League of Nations felt compelled to agree despite his previous objections. The Council immediately unanimously approved the recommendation.

Yugoslavia, however, refused to implement the decision of these three international

19 MEPJ, Arkivi historik 1928-1932.

20 MEPJ, Arkivi historik 1928-1932.

21Permanent Court of International Justice, no. 9, p.23, 4 September 1924, op. cit. Pearson pp. 229-230 
institutions. At that moment, neither the League of Nations nor Albania had the means to force Belgrade to evacuate Albanian territories and to respect the League's decision. To avoid conflicts, it was decided to wait for an alternative solution initiated by the respective countries.

Given these facts, it was clear that St. Naum had played a very special role in obtaining Yugoslav support for Zog's return. In fact, from the beginning, everyone had suspected that there was a close relationship between him and the Yugoslavs and that he had to pay his price in exchange for their support. Senior Serbian officials urged the Conference of Ambassadors not to insist on the League's recommendations, explaining that the Yugoslav government had hoped to reach an agreement with Albania on St. Naum, exchanging it for one or two border villages "of dubious nationality"22 - this confirmed all suspicions. The Yugoslav scholar Zh. Aveamovsky ${ }^{23}$ had reached the same conclusion, referring to a report written by an employee of the Albanian section of the Ministry of Foreign Affairs in Belgrade, who had served for several years in the Albanian League in Tirana. Based on this, Avramovsky ${ }^{24}$ made a summary of the secret agreement between Zog and Pašic:

A. Zog would not refuse the annexation of St. Naum to Yugoslavia and would once again raise the issue of pastures in Vermosh and the lanes towards it.

B. Zog would split the "Kosovo National Defense" committee and all guerrillas operating in Yugoslav territory would be found as usual.

C. The Yugoslav Government will guarantee its influence over the Albanian Orthodox Church.

D. Zogu promised to resolve the issue of Serbian schools in Shkodra and the village of Vraka, and will open schools in Macedonian villages in the district of Korca.

E. Both parties that have reached an agreement to start trade negotiations, concluded the relative agreement and immediately reviewed the border retail business.

F. Zog had promised to open a bank with mainly Yugoslavic capital in Albania.

G. Albania will not enter into any agreement or accept any loan for the construction of the railway without first consulting the Yugoslavic government.

H. Yugoslav ships would have a privileged position in Albanian ports and in the lakes of Ohrid and Shkodra.

Although this version may seem more moderate, it does not touch on Belgrade's intention to establish a pro-Yugoslav regime in Albania. The truth is that on February 21, 1925, shortly after Zog came into force, in a letter to the Chargé d'Affaires of the Serbo-Croatian-Slovenian Kingdom in Tirana, the new Albanian government informed the Yugoslav authorities that it was considering the case of St. Naum and Vermoshi and proposed an exchange of territories for the final settlement. He was ready to leave the territories of the Monastery of St. Naum and Vermosh in exchange for the Banisht region in Debar and the Has plain near Prizren. The UK considered it not worth risking a real conflict on this issue at a time when the Serbs would have it at all costs and when Albania was unable to take any action. ${ }^{25}$ In May 1925 Yugoslavia seemed to agree to give Albania the village of Peshkopi and to drop its claims over the Vermosh plain in exchange for the Monastery of St. Naum and north of Vermosh. ${ }^{26}$ Thus, the Yugoslav talks, held under the great pressure of the Conference of Ambassadors and the compromises proposed by him, brought a solution on October 5, 1925, according to which St. Naum was ceded to the Kingdom of Croatia and Slovenia in exchange for the village of Peshkopi with 6o houses and 300 inhabitants and for some other small concessions: Çërava Plain, Blessed Water Church (Ajazma) and strategic hills no. 961, 965, 807, 868, which surrounded the monastery building and the guard tower of the Yugoslav border guards. In the north, in exchange

22cit. Milo p. 302

23ArhivJugosllavije, Fund 37, fascicle 379, report of I. Vukovic for the Prime Minister and Minister of Foreign Affairs of Yugoslavia M. Stojadinovic, Belgrade, 3 February 1939 op.cit. Milo p. 302

24 ArhivJugosllavije, Fund 37, fascicle 379, report of I. Vukovic for the Prime Minister and Minister of Foreign Affairs of Yugoslavia M. Stojadinovic, Belgrade, 3 February 1939 op.cit. Milo p. 302

25DBFP; vol. XXVI, doc. 305, n.6, 25 December 1925

26ASCA, File 730, p. 249, Report of the Albanian Chargé d'Affaires to Belgrade, P. Pekmezi, to Ahmet Zog, 30 April 1925 
for the western valley of Vermoshi, the valleys of Velipoja, the pastures of Libohova were returned to Albania and some small concessions were made. ${ }^{27}$

After constant pressures, the intervention of the internationals, relying on the Conference of Ambassadors in London in 1913, Serbia took the decision and withdrew from the claims of secret agreements made between the governments and now St. Naum was part of the Albanian territory.

Serbian authorities were initially reluctant to make all these concessions. They had agreed to leave Albania, but only the village of Peshkopi and part of Libohova. However, they quickly changed their position and agreed to make an agreement with Albania. What had happened in the meantime? In early August, Belgrade had reached a secret agreement between Albania and Italy. So they had no interest in worsening they relations with the Government of Tirana. Instead, they were more inclined to close the issue in order to be able to effectively challenge a future rapprochement between Rome and Tirana.

The Albanian Legislative Assembly approved the compromise agreement at a joint meeting of the Chamber of Deputies and the Senate on October 14th and no doubt ratified the issue of territory in Yugoslavia, including the Monastery of St. Naum. The Albanian government informed the Conference of Ambassadors about the conclusion of this agreement and entrusted them with the demarcation of the border. The border question was finally closed on 30 July 1926, under the new Protocol signed in Florence on 27 January 1925, ratified in Paris by delegates to the Conference of Ambassadors of France, Great Britain, Italy and Japan, and were opposed by representatives of Albania, Greece and Yugoslavia. ${ }^{28}$ Thus, fourteen years after its independence, Albania was no longer a "geographical" term. ${ }^{29}$ With this act, Zogu paid part of the price for his Yugoslav aid in December 1924. The border question was finally closed, but the corrections continued to cause tension between Albania and its neighbors on an ongoing basis because they still wanted what our neighbors wanted us to do.

\section{Conclusion}

Zogu's active policy with neighboring countries was very important for the protection of Albanian territory and for the stability of policies with internationals.

Zog's relationship with Mussolini was important not only in strengthening power in his positions but also in determining the fate of Albanian territory. Firstly, we are dealing with the territorial protection of the Adriatic coast from Zog's diplomatic relations with Italy.

Secondly, the first project presented to Zog with the aim of transforming Albania into a Yugoslav region with limited local autonomy with Zogu as its ruler. Avramovski's version could indeed be the agreement concluded after negotiations between the parties. It was Zog's style to maneuver by not getting involved in compromising documents however, in the second deal.

Third, St. Naum had played a very special role in gaining Yugoslav support for Zog's return. Senior Serbian officials urged the Conference of Ambassadors not to insist on the League's recommendations, explaining that the Yugoslav government had hoped to reach an agreement with Albania on St. Naum. But this did not result in a complete decision because the Conference gave the right of territorial settlement to Albania from where St. Naum remained within the borders of Albanian territory.

27Ibid., File 728, p. 249, Report of the Chairman of the Legislative Assembly to the Council of Ministers, 20 July 1925 28Ibid., File 65, p. 251, Protocol of the delimitation of the Serbian-Croatian-Slovene - Albanian frontier at Florence, 26 July 1926

29 Ibid., File 65, p. 251, Protocol of the delimitation of the Serbian-Croatian-Slovene - Albanian frontier at Florence, 26 July 1926 


\section{References}

ASCA, File 730, p. 249, Report of the Albanian Chargé d'Affaires to Belgrade, P. Pekmezi, to Ahmet Zog, 30 April 1925 ASCA, Fund 251, File 105, pg. 3 ( Reference Archive)

ASCA, Fund 251, File 105, pp. 4-5, 1925 (Reference Archive)

Cici Arben., "Marrëdhëniet Shqiptaro Italiane" AFERDITA,, p. 62, op. cit. IDD, vol. III, n. 66o, pp. 404-405

DBFP, vol. XXVI, doc. 312, n. 5 (Archive References Foreign Policy Documents)

DBFP; vol. XXVI, doc. 305, n.6, 25 December 1925 (Archive References Foreign Policy Documents)

Fischer Bernard, King of Albania fq. 105

George Curzon 1st Marquess of Kedleston FO 371/8535, Dibra op. cit. pg. 226

MEPJ, Arkivi historik 1928-1932

Milo, Paskal, Politika e Jashtme e Shqipërisë, Botimet Toena,2013 fq. 334-335,

Pastorelli Poetro., "Italia e Albania 1924-1927 Biblioteca della "Rivista di studi politici internazionali" in Firenze", pp. 221-222

Permanent Court of International Justice, no. 9, p.23, 4 September 1924, op. cit. Pearson pp. 229-230

Protocol of the delimitation of the Serbian-Croatian-Slovene - Albanian frontier at Florence, 26 July 1926, File 65, p. 251

Report of the Chairman of the Legislative Assembly to the Council of Ministers, 20 July 1925 File 728, p. 249

Tomes, Jason. King Zog, Self-Made Monarch of Albania, 2003 pg. 78

Ushtelenca Ilir. "Diplomacia e mbretit Zogu i Pare" Shtëpia Botuese "Ermir", 1997 Tiranë 


\section{TR RICHTMANN}

Richtmann Publishing Ltd,

Registered In England and Wales

Reg. No. 09517713 Reg. Office: Office 1,

Forest House Business Centre,

8 Gainsborough Road,

London, England, E11 1HT

Web: https://www.richtmann.org

E-mail:mjss@richtmann.org 